\title{
Comparative ecology of marine and freshwater phytoplankton ${ }^{1}$
}

\section{Peter Kilham}

Department of Biology and the Great Lakes Research Division, University of Michigan, Ann Arbor 48109-1048

\section{Robert E. Hecky}

Department of Fisheries and Occans, Freshwater Institute, 501 University Crescent, Winnipeg, Manitoba R3T 2N6

\begin{abstract}
Examination of models of nutrient-limited growth and uptake, nutrient patchiness, resource competition, and $r$ - and $K$-selection with respect to marine and freshwater phytoplankton indicates that organisms from both habitats are ecologically similar. However, there are differences in the physiology and ecology of phytoplankton within a given habitat (either marine or freshwater) during the course of succession. Even though the identity and basic ecology of organisms that are present early and late in successional sequences are generally known, little is known about their physiology. Marked differences in uptake ability, storage capacity, and growth and loss rates will be found for phytoplankton that can be ranked along an $r$-through $K$-selection continuum. This continuum can serve as a unifying concept in phytoplankton ecology.
\end{abstract}

There are numerous similarities between marine and freshwater phytoplankton, but papers and reviews that deal with their ecology often restrict coverage to organisms from one habitat or the other. In this paper we will examine a variety of topics currently of interest to phytoplankton ecologists in order to determine similarities or differences between phytoplankton from each environment. These topics include models of nutrient-limited uptake and growth, nutrient patchiness, resource competition, and $r$-and $K$-selection. Several books on the ecology of marine (Morris 1980; Platt 1981; Carpenter and Capone 1983) and freshwater (Reynolds 1984) phytoplankton have appeared recently, and they should be consulted for detailed information.

In this review we will also contrast and compare the ecology and physiology of marine and freshwater phytoplankton that can be found along gradients of resource availability (e.g. varying nutrient levels) in either environment.

There are substantial differences in the proportions of phytoplankton species representing the major divisions of algae in marine and freshwater environments, and sev-

\footnotetext{
1 An international travel award from the National Science Foundation supported travel to the Symposium on the Comparative Ecology of Freshwater and Coastal Marine Ecosystems in Nairobi, Kenya.
}

eral important groups (classes and orders) are representative of one habitat or the other. The marine phytoplankton is dominated by numerous species of Chrysophyta (diatoms, coccolithophores, and silicoflagellates: Bold and Wynne 1985) and Pyrrhophyta (dinoflagellates). Several other groups of algae are at times either conspicuous or abundant, but they are represented by very few species. These include the Cyanophyta [=cyanobacteria; e.g. very small-celled species of Synechococcus or large bundles of Oscillatoria (Trichodesmium) filaments]. Another characteristic member of the marine phytoplankton is Halosphaera (division Chlorophyta, class Prasinophyceae), which has spherical green cells.

Freshwater phytoplankton is well represented by species of most of the major divisions of algae that have a planktonic component. Therefore, a plankton sample from a lake may contain Cyanophyta, Chlorophyta, Chrysophyta, and Pyrrhophyta. Euglenophyta, which can usually be found in small ponds, are not common members of the freshwater phytoplankton (Round 1981). A large number of species of Chlorophyta and Cyanophyta are found in freshwater, but not in seawater. Coccolithophores, which are characteristic of marine plankton, are rarely observed in freshwaters.

Marine and freshwater ecologists generally approach the study of phytoplankton 
from different points of view. Because the oceans comprise $71 \%$ of the earth's surface, marine phytoplankton clearly plays a significant role in the global biogeochemical cycling of carbon, nitrogen, phosphorus, silicon, and many other elements (Broccker 1974). Marine phytoplankton ecologists often investigate the flows of energy and materials in the pelagic environment. There is also an emphasis on the measurement of collective properties such as primary production, chlorophyll $a$, the uptake of ${ }^{15} \mathrm{~N}-$ labeled compounds, $C: N: P$ ratios, etc. Collective properties are studied in part because automated measuring techniques are often available and the identities of the organisms do not have to be known. The ecology of individual species is rarely studied because the workis time-consuming and may not contribute much to our understanding of global biogeochemical cycles. With a few exceptions, the marine ecologists who study phytoplankton are ecosystem ecologists.

Phytoplankton ecologists working in freshwaters generally take a more speciesoriented approach to their reasearch, although excellent studies from an ecosystems perspective have also been done. The biological properties of individual species are considered to be of great interest. Freshwater biologists emphasize the ecological factors that govern the distribution, abundance, and evolution of phytoplankton species. For example, studies are conducted to examine the effects of nutrient-limited growth, resource competition, and loss processes on the population dynamics of individual species or groups of species.

We give special thanks to S. S. Kilham for her aid, knowledge, and scientific advice. F. P. Healey provided a detailed review. We thank E. J. Carpenter, R. L. Kiesling, J. M. Melack, C. S. Reynolds, and R. L. Thompson, $\mathrm{Jr}$., for comments and suggestions.

\section{Models of nutrient-limited growth and uptake}

Several comprehensive reviews have recently appeared on the kinetics of nutrient utilization by phytoplankton and other microbes (Goldman and Glibert 1983; Button 1985); however, it is still not easy to ascertain the appropriate names for some of the equations that describe the growth and uptakc kinetics of algae. The Monod equation (Monod 1942) is used to show the direct relationship between the external nutrient concentration and the growth rate of an alga or bacterium at steady state. The Monod, Michaelis-Menten, and Droop equations discussed here are presented in Tables 1 and 2 and illustrated graphically in Goldman and Glibert (1983).

If the Monod equation was the only one used to describe the kinetics of nutrientlimited growth in relation to external substrate concentration there would be little confusion, but Dugdale (1967), in his paper on nutrient limitation in the sea used the Michaelis-Menten equation, adopted from enzyme kinetics, to describe steady-state nutrient uptake by an alga with respect to external nutrient concentration. This has led to confusion, because the Michaelis-Menten equation is equivalent to the Monod equation at true stcady state. Under steadystate conditions, the specific uptake rate can be equated to the specific growth rate, but the names of these equations should not be used interchangeably. Another complication is that are several commonly used expressions for uptake that follow the Michaelis-Menten form but are evaluated in terms of different units. For example, specific uptake has the units time ${ }^{-1}$, while the uptake parameter for transient transport has the units mass volume ${ }^{-1}$ time $^{-1}$ (here mass volume $^{-1}$ usually means mass cell ${ }^{-1}$; see Table 2).

It is difficult to compare data on nutricntlimited growth and uptake for marine and freshwater phytoplankton. Because marine algae are often thought to be nitrogen limited (see Carpenter and Capone 1983; Hecky and Kilham 1988), the kinetics of nitrogenlimited growth and uptake are studied more frequently than the kinetics of other nutrients. In freshwaters where silicon or phosphorus are at times believed to limit algal growth, the kinetics of these nutrients are often investigated. The major problem that one encounters is that most of the data on the kinetics of marine phytoplankton are for uptake and transient transport (using the Michaelis-Menten equation). In contrast, the kinetics of nutrient-limited growth is often 
Table 1. Steady-state equations that describe nutrient-limited growth by phytoplankton. The Monod equation relates growth rate to external nutrient concentrations; the Droop cquation relates growth ratc to intcrnal nutrient stores (see Droop 1974, 1983; Kilham 1978; Goldman and Glibert 1983).

\begin{tabular}{|c|c|c|}
\hline & Equation & Variables \\
\hline Monod & $\mu=\mu_{m}\left[\frac{S}{K_{u}+S}\right]$ & 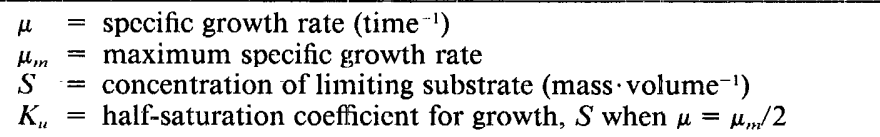 \\
\hline Droop & $\mu=\bar{\mu}\left[1-\frac{k_{Q}}{Q}\right]$ & $\begin{aligned} \mu= & \text { specific growth rate }\left(\text { time }^{-1}\right) \\
\bar{\mu}= & \text { spccific growth rate at infinite internal substrate concentration } \\
Q= & \text { cell quota of limiting nutrient (cellular nutrient mass } \div \text { total } \\
& \text { cellular mass) } \\
k_{Q}= & \text { subsistance quota, } Q \text { at } \mu=0\end{aligned}$ \\
\hline
\end{tabular}

determined for freshwater algae (using the Monod equation). As mentioned above, data for specific uptake have the same units $\left(\right.$ time $\left.^{-1}\right)$ as data for growth at steady state, but specific uptake information is seldom collected under steady-state conditions. Therefore, the data obtained are often not equivalent.

Biological oceanographers probably prefer to study the kinetics of nutrient uptake and transient transport because these data are compatible with Dugdale's (1967) and subsequent models of nutrient limitation in the sea. In addition, one can directly measure the uptake or transient transport of ${ }^{15} \mathrm{~N}$ labeled compounds by phytoplankton populations collected at sea. Marine ecologists question the utility of the Monod equation because it does not work well for ammonium-limited growth (Goldman and McCarthy 1978). The problem is that Thalassiosira pseudonana $(3 \mathrm{H})$ and probably other small algae can grow at about $80 \%$ of their maximum growth rates while ammonium concentrations remain immeasurable. Despite this problem, many freshwater biologists prefer to use the Monod equation to study nutrient-limited growth. This equation appears to work reasonably well for two of the nutrients believed to be limiting in freshwater systems (phosphorus and silicon; see table 1 of Tilman et al. 1982), and data on nutrient-limited growth are required if one wishes to study the population dynamics and competitive interactions of individual species. Models of resource competition for freshwater phytoplankton incorporate the Monod equation because this simple relationship has been shown to be as effective as more complex relationships (known as the variable internal stores model) developed from the Michaelis-Menten (transient transport) and Droop equations (see below; see also Tilman 1977).

Marine and freshwater phytoplankton ecologists have had their particular prefer-

Table 2. Steady-state or transient-state (or both) equations that describe nutrient uptake or transport by phytoplankton (see Kilham 1978; Goldman and Glibert 1983; Button 1985). The transient-transport equation is from Goldman and Glibert 1983.

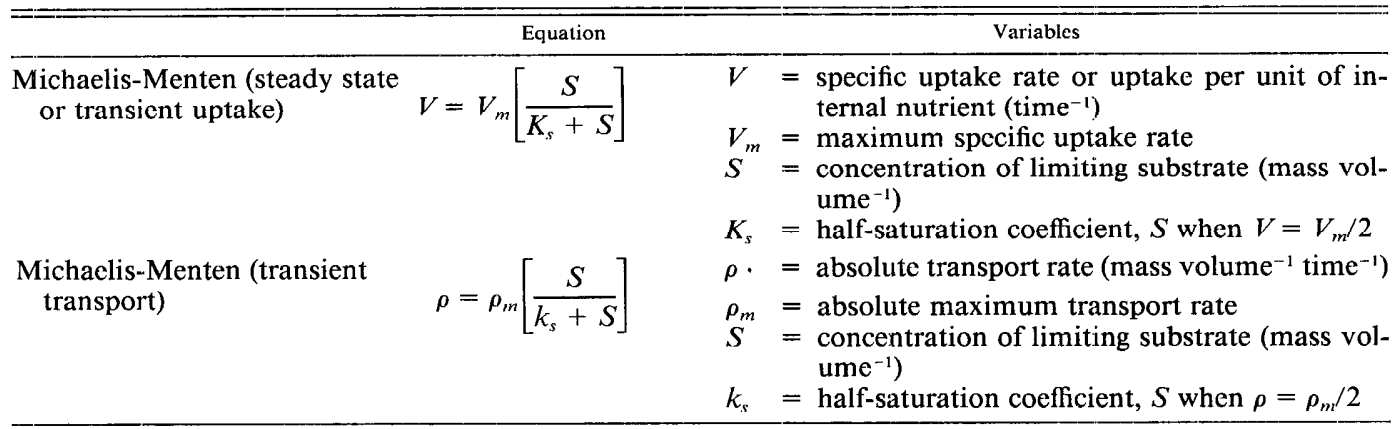


ences regarding the use of the Monod equation and various applications of the $\mathrm{Mi}$ chaelis-Menten equation, but there is apparent agreement that the Droop equation (Table 1) can be used for most limiting nutrients. However, the equation applies less well as the nutrient in question occupies a larger fraction of the cell (Goldman and McCarthy 1978). The Droop equation relates growth rate to intracellular nutrient concentrations. It is discussed in detail by Droop (1974, 1983), Rhee (1980), and Goldman and Glibert (1983). Experiments designed to study particular species of algae using the Droop relationship are done on populations grown to steady state in a continuous culture. One drawback, however, is that the Droop equation only relates cell quota to growth rate. Therefore, the effect of external nutrient concentration cannot be easily cvaluated. It has also been discovered that the Droop equation does not hold for the cell quotas of nonlimiting nutrients (Elrifi and Turpin 1985).

The major practical problem with using the Droop relationship is that it has to be evaluated with chemostat technology. Unfortunately, chemostats, no matter how simple, require a large effort. Steady state Monod experiments are easier to perform (Tilman 1977; Tilman and Kilham 1976; Kilham 1978) and work well for many nutrients. Marine ecologists prefer Droop experiments over Monod experiments because for nitrogen and many other nutrients the cell quota $(Q)$ is easy to measure even if the Droop equation is sometimes difficult to apply. As pointed out above, the Monod equation cannot be profitably used when limiting-substrate concentrations are below the limit of detection.

The basic equations that describe nutrient-limited growth and uptake for marine and freshwater phytoplankton can be used for algae from both environments. It is also encouraging that most nutrients are utilized in a similar manner, even though a few minor exceptions have been found (e.g. the relationship between nitrogen cell quotas and growth when calculated with the Droop equation). However, two problems are encountered when one attempts to compare the physiological research carricd out by dif- ferent investigators. First, both the general terminology and the symbols used for specific parameters vary between studies. Second, and more importantly, most of the theoretical relationships that describe nutrient-limited growth and uptake only apply under steady-state conditions. Consequently, one must be certain that experimental data obtained are actually steady-state and not transient-state data (unless transientstate data are required). Problems such as these make it difficult to evaluate data on nutrient uptake (Goldman and Glibert 1983).

\section{Nutrient patchiness}

The potential importance of nutrient patchiness in determining the growth rates of individual species of phytoplankton and, concomitantly, the structure of phytoplankton communities is one aspect of their ecology that has received balanced attention from limnologists and oceanographers. At about the same time, McCarthy and Goldman (1979) and Turpin and Harrison (1979) independently recognized the potential significance of nutrient patchiness to planktonic algae in coastal and oceanic environments. On the basis of their laboratory research, McCarthy and Goldman (1979) provided additional evidence that nutrientstarved phytoplankton from the open ocean have markedly enhanced uptake capacities for limiting nutrients. They proposed that enhanced uptake ability would permit an alga to obtain nutrients from small-scale nutrient patches such as those that might result from zooplankton excretion. As a result, they argued that phytoplankton populations should be able to maintain nearly maximum growth rates in nutrient-depleted waters. However, phytoplankters growing near their maximum growth rate do not have enhanced uptake rates, and they would not be able to utilize nutrient patches as effectively as slower growing, nutrient-starved algae.

Turpin and Harrison (1979) studied the effect of nutrient pulses on the community structure and species succession of phytoplankton, which they obtained from nature and maintained in the laboratory. They initially found that the homogeneous delivery 
of ammonium (the limiting nutrient) to their continuous cultures favored members of the genus Chaetoceros, and Skeletonema costatum dominated when ammonium was added as a daily pulse (patchy distribution). In subsequent experiments, ammonium was added weekly and resulted in dominance by Thalassiosira nordenskioldii (Turpin and Harrison 1980; Harrison and Turpin 1982).

Freshwater biologists were intrigued by Jackson's (1980) provocative work in which he suggested that small-scale patches might not persist long enough to be utilized by the phytoplankton. Lehman and Scavia $(1982 a, b)$, working with Chlamydomonas reinhardti and Daphnia pulex in the laboratory, experimentally demonstrated the occurrence, persistence, and algal utilization of small-scale patches that were produced by zooplankton excretion.

The potential role of patchiness in determining the community structure of freshwater phytoplankton communities has also been studied in the laboratory with populations obtained from nature. Scavia et al. (1984) found that their patch cultures were dominated by the blue-green alga Schizothrix calcicola, while control cultures that did not receive additional nutrients were dominated equally by $S$. calcicola and several other species of algae. In patch culture experiments, a sample from a semicontinuous culture is enriched for a short period of time each day and then returned to the culture vessel.

The most comprehensive investigation of this type to date is that of Sommer (1985a) who studied competition within natural communities of algae from Lake Constance (Germany). Experiments were conducted with a chemostat (continuous nutrient supply) and two continuous culture systems (pulsed nutrient supply) of similar design. One continuous culture received a weekly pulse of phosphorus and the other received a weekly pulse of both silicon and phosphorus. For each experiment, the $\mathrm{Si}: \mathrm{P}$ input ratio was $20: 1$. In the chemostat experiment only two species persisted for more than 5 weeks (Synedra acus and Koliella spiculiformis). But, in the pulsed $\mathrm{P}$ competition experiment, six species coexisted. Mougeotia thylespora, Diatoma elongatum,
Aphanizomenon flos-aquae, and Pediastrum duplex were stable species that fluctuated little, while Scenedesmus quadricau$d a$ and Chlorella sp. oscillated. Finally, in the pulsed $\mathrm{P}$ and $\mathrm{Si}$ experiments (Fig. 1), there were nine species that coexisted (four were stable species and five were oscillating). Sommer's experiments showed that different species of algae had varying responses to nutrient pulses and that three broad categories of response could be identified: stable, oscillating, and excluded.

Research on nutrient patchiness has revealed that individual species of algae respond quite differently to low, homogeneous nutrient levels and to nutrient pulses. Species that dominate in chemostats with uniformly low nutrient levels are termed "affinity specialists" (Sommer 1985a; Turpin and Harrison 1979). Healey (1980) defined nutrient affinity as the initial slope of the Monod growth curve (or the Michaelis-Menten uptake curve). In Sommer's chemostat experiments, $S$. acus and $K$. spiculiformis were identified as affinity specialists. In their experiments using marine communities, Turpin and Harrison (1979) found that Chaetoceros species had a high affinity for ammonium.

Apparently, both marine and freshwater algae respond to nutrient pulses in a similar manner. Sommer's (1985a) observations on pulsed continuous cultures indicate that a continuum of responses probably occurs, with pure "velocity specialists" at one end of the spectrum and "storage specialists" at the other. Velocity specialists rapidly consume a nutrient pulse and almost immediately utilize the acquired nutrient for growth. Storage specialists, on the other hand, can take up nutrients from a pulse, but they store the nutrients obtained in an intracellular storage pool (i.e. luxury consumption). The behavior of individual species in Sommer's experiments indicated to him that species producing stable populations were affinity specialists in the chemostat expcriments and storage specialists in the pulsed continuous culture experiments. Oscillating species were velocity specialists.

Despite the results of experimental and theoretical investigations concerning nu- 


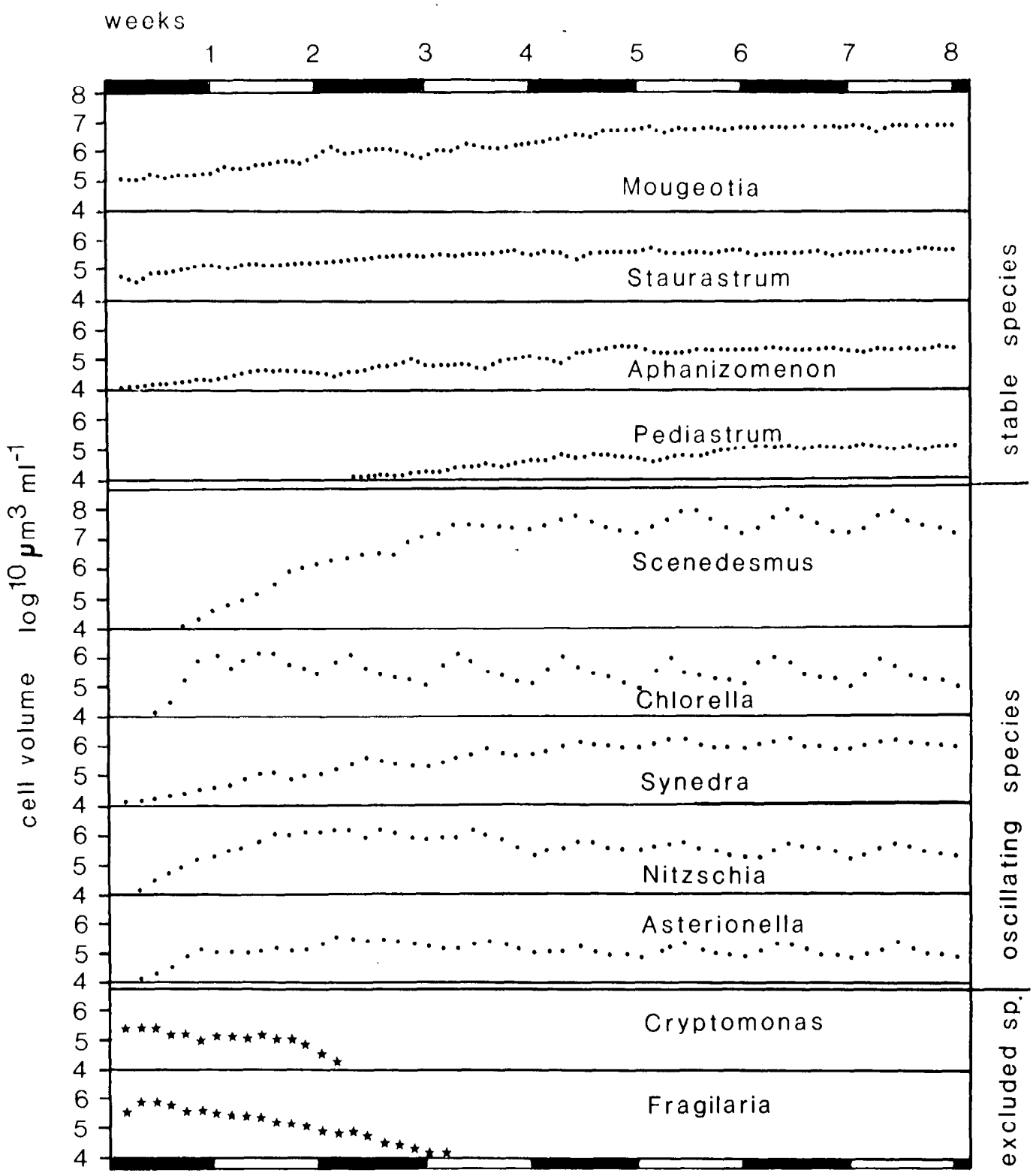

Fig. 1. Pulsed competition experiment. The culture received weckly pulses of $\mathrm{P}$ and $\mathrm{Si}$ at $\mathrm{Si}: \mathrm{P}=20$. Species included in this figure contributed $>5 \%$ of the total biomass at some time during the experiment. (Redrawn from Sommer 1985a.)

trient patchiness, there are few studies that demonstrate the significance of nutrient patchiness to phytoplankton populations in nature. Goldman and Gilbert (1983) pointed out that the utilization of small-scale nutrient patches is only one of the mechanisms that might allow phytoplankton to grow comparatively rapidly in nutrient-depleted environments. Phytoplankton might also obtain sufficient nitrogen from the low ambient levels found in a relatively homogeneous environment, in which case nutrient uptake from small-scale patches would not be necessary (see also Currie 1984; Lehman and Scavia 1984). Moreover, studies with ${ }^{15} \mathrm{~N}$ isotope dilution techniques show that 
rates of nutrient regeneration in oceanic waters are commonly equal to and occasionally larger than the nutrient uptake rates of the phytoplankton (Goldman and Glibert 1983; Harrison 1983).

Reinertsen et al. (1986) have carried out the most "natural" study concerning nutrient patchiness reported to date. They studied interspecific competition for phosphorus between Anabaena flos-aquae (a blue-green alga) and Staurastrum luetkemuelleri (a desmid) in experimental enclosures. Experimental treatments included adding zooplankton and fish. The addition of zooplankton primarily enhanced the growth of $S$. luetkemuelleri because this affinity specialist was able to effectively utilize the more or less homogeneous supply of phosphorus that they suggest results from zooplankton excretion (small-scale patches were not mentioned). Anabaena flos-aquae grew best in enclosures containing fish. This alga is apparently a storage specialist capable of rapidly taking up the large pulses of phosphorus that are produced by fish excretion. Generally similar results were obtained by Sakshaug and Olsen (1986) for a laboratory (chemostat) investigation of competition between $S$. luetkemuelleri and Microcystis aeruginosa (a blue-green alga). Microcystis aeruginosa also appears to be a storage specialist that can utilize large pulses of nutrients.

\section{Resource competition}

Over the past decade, studies of resource competition among freshwater phytoplankters have become increasingly sophisticated, and it is now possible to argue that resource competition is of considerable importance in structuring natural communities of freshwater phytoplankton (Tilman et al. 1982; Kilham and Kilham 1984; Sommer 1985h). Similar claims cannot be made regarding phytoplankton communities in the marine environment, but experimental investigations of the type used by freshwater biologists have not been carried out on marine organisms.

One approach to predicting the outcome of competition among freshwater algae for two limiting resources is to perform Monod growth experiments for each species under substrate-limiting conditions. From these experiments one obtains $\mu_{m}$ (the maximum growth rate) and $K_{u}$ (the half-saturation coefficient for growth). These "constants" are then used to calculate $R^{*}$ values for each species limited by each resource using:

$$
R^{*}=D K_{u} /\left(\mu_{m}-D\right)
$$

where $D$ is the dilution or mortality rate at which the competition experiment will be performed and $R^{*}$ is the concentration of the limiting nutrient required by an alga to grow at the specific dilution rate $(D$, Fig. 2$)$. The species with the lowest $R^{*}$ for a resource should be the competitive dominant for that resource (Tilman 1982). The minimum cell quotas $\left(k_{Q}\right)$ for each species under each type of nutrient limitation are also needed to predict the outcome of competition (Tilman 1981). These data can be obtained from steady state continuous culture experiments which can also be used to determine the growth of each species in unialgal culture. These steady state cultures therefore serve as controls for multispecies competition cxperiments. Another approach is to use a simple batch culture method developed by Rhee and Gotham (1980) for determining minimum cell quotas.

An alternate to the Monod model of competition is the variable internal stores model. This model is evaluated using transient transport and Droop equations (Tables 1, 2). Both models make similar predictions (Tilman 1977; Kilham 1978).

The predicted outcome of a competition experiment involving two species and two potentially limiting nutrients is shown graphically in Fig. 3. The isoclines of zero net growth are defined by the $R^{*}$ values for each species and each resource. The rate at which each species consumes both resources is represented as a consumption vector. The ratio of the minimum cell quotas for each nutrient for a species gives the slope of the consumption vector. This slope is also called the optimum ratio. Terry et al. (1985) and Elrifi and Turpin (1985), however, have recently argued that optimum ratios are growth rate-dependent. Healey (1985) has indicated that optimum ratios are light-dependent. Despite these 


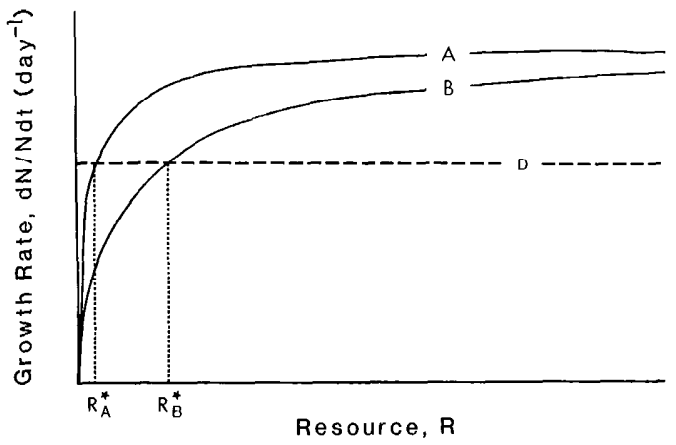

Fig. 2. Monod growth curves for two species (A and $\mathrm{B}$ ). For steady state conditions, $R^{*}$ values can be determined graphically. The $R^{*}$ value for each species is the equilibrium resource concentration at specific dilution rates ( $D$ equals mortality rate at stcady state). In a chemostat, $R^{*}$ represents the residual amount of $R$ once an equilibrium has been established, with $R$ as a limiting resource (Tilman et al. 1982). When two species (A and B) compete for a single resource, the species with the lowest $R^{*}$ for that resource will always win.

complications, no problems have yet been encountered in the use of graphical techniques to analyze competitive interactions (see Tilman 1981, 1982; Tilman et al. 1982), but Turpin (1986) suggested that changes in the optimum ratio with growth rate may alter the breadth of zones of coexistence or facilitate their formation or elimination.

Resource competition in marine and freshwater phytoplankton has been reviewed by Maestrini and Bonin (1981). Their review gives one the impression that studies of competition are generally entirely theoretical or a mixture of theoretical and laboratory studies. At present, field studies of competition among phytoplankton usually involve correlation analysis, not experimentation.

The resource ratio hypothesis has bcen rigorously tested in the laboratory by several investigators working independently (e.g. Tilman 1981; Holm and Armstrong 1981; Sommer 1983), but it has not been experimentally investigated under field conditions. Despite this, correlation analysis of diatom distributions and water chemistry indicates that resource competition is probably important in structuring the diatom communities of Lake Michigan (Tilman et al. 1984; Kilham 1986; Kilham and Titman

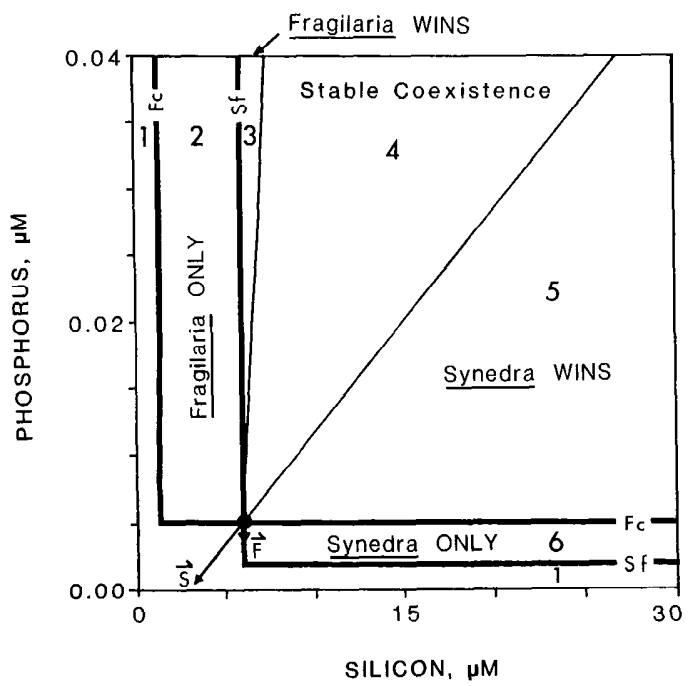

Fig. 3. The predicted outcome of resource competition between two freshwater diatoms, Synedra filiformis $(\mathrm{Sf})$ and Fragilaria crotonensis $(\mathrm{Fc})$, for phosphorus and silicon. The isoclines of zero net growth (heavy lines) for each species cross at an equilibrium point (@). The consumption vectors for each species are labeled $\vec{S}$ and $\vec{F}$. Six regions of species interaction are defined by the isoclines of zero net growth and consumption vectors. Neither species has sufficient nutrients to survive in region 1 . In region 2 Fragilaria can survive, but Synedra cannot. In region 3 Synedra is outcompetcd by Fragilaria. Both species stably coexist in region 4. Fragilaria is competitively displaced by Synedra in region 5. Only Synedra can survive in region 6. (Redrawn from Tilman 1981.)

1976; Tilman 1977). Resource competition is also thought to be important in determining the course of seasonal succession in Lake Constance (Sommer 1985b) and the distribution and abundance of many common diatom species in the lakes of east and central Africa (Kilham et al. 1986).

Competition among marine phytoplankton for limiting concentrations of inorganic nitrogen has been studied sporadically since Dugdale (1967) originally found that marine diatoms with intersecting (crossing) Michaclis-Menten (or Monod) curves apparently compete with one another and that the outcome of competition could be predicted from the shapes of the curves. Expcrimental research to examine the validity of Dugdale's fundamental observations culminated in the chemostat study of competition among marine diatoms by Mickelson et al. (1979). For a variety of reasons given 

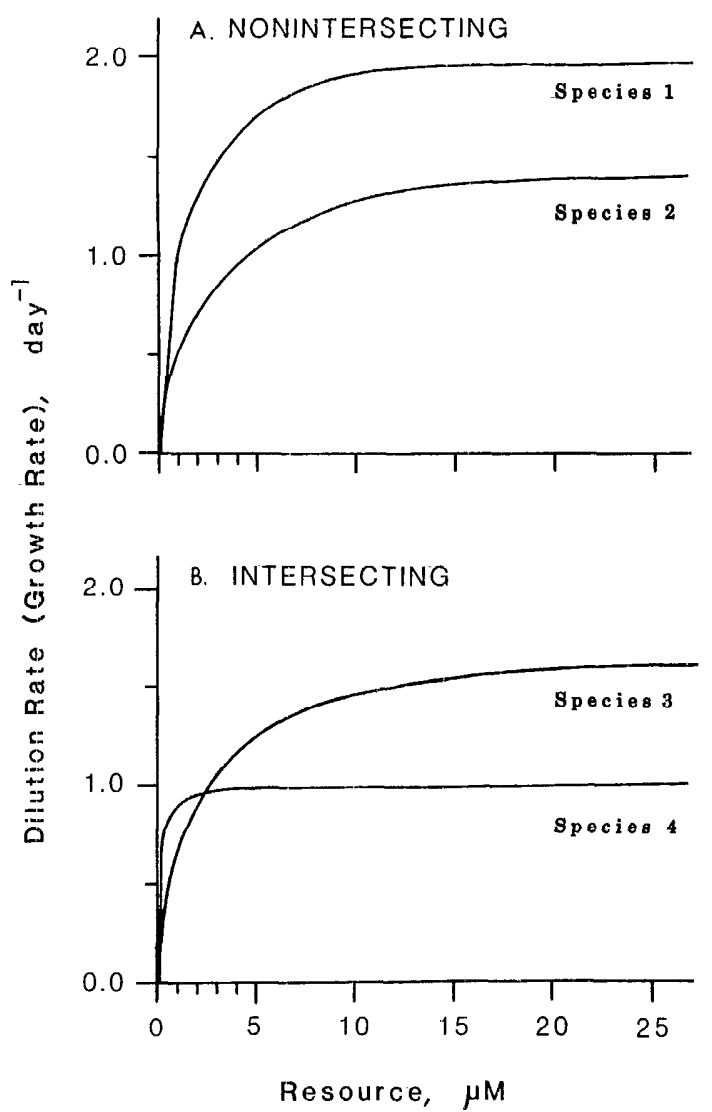

Fig. 4. Nonintersecting and intersecting Monod curves for several hypothetical spccies that compete for a single resource under steady state conditions over a range of dilution rates (=growth rates in a chemostat) A. When Monod curves are nonintersecting, the species (1) with the lowest $R^{*}$ value at all dilution rates will be the competitive dominant. B. When Monod curves intersect, the species (4) with the lowest $R^{*}$ value will win at dilution rates below the point of intersection. Above the intersection point, the species (3) with the highest maximum growth rate will win. This type of interaction represents a tradeoff between low $R^{*}$ values and high maximum growth rates. Under natural conditions during the period of nutrient limitation, growth rates are not as variable as the dilution rates shown here, and competition for two or more potentially limiting resources may be of greater importance than competitive outcomes detcrmined by changes in turnover rate within a lake.

in their paper, they expected to find that the Monod growth curves of the diatoms they studied would intersect, but they did not. However, the Monod curves obtained were still useful in predicting the outcome of competition.
Experience with freshwater algae indicates that intersecting growth curves predict the outcome of competition only in cases where the dilution rate (growth rate in a chemostat) is changed and where only one continuously supplied resource is potentially limiting (Fig. 4). In phosphorus-limited chemostats with a natural phytoplankton community as an inoculum, Smith and Kalff(1983) showed that one species, S. acus, dominated in every case over a wide range of turnover rates, presumably because it had the lowest $R^{*}$ for phosphorus (Sommer and Kilham 1985; Sommer 1986). The general shape of the Monod growth curves, whether intersecting or not, are important because they determine the $R^{*}$ values at specific dilution rates.

Onc can easily describe resource competition among several species for a single resource in terms of $R^{*}$ values (Tilman 1981, 1982), with the species having the lowest $R^{*}$ value becoming the competitive dominant. But theory (Tilman 1982), the results of experiments designed to investigate competition (Tilman 1977), and the biology of the algae themselves (Tilman et al. 1982) indicate that competition usually involves at least two resources. The results of competition experiments with laboratory cultures and whole community experiments with natural populations show that the outcorne of competition and the course of succession can be predicted if the phytoplankton are competing for at least two resources. Indeed, potentially competing planktonic diatoms appear to have evolved in such a way that a species with a low $R^{*}$ for phosphorus will have a high $R^{*}$ for silicon. Thus, one can draw an interspecific resource tradeoff curve illustrating the relative competitive abilities of commonly dominant planktonic diatoms for silicon and phosphorus (Fig. 5). It should also be pointed out that because of this tradeoff the halfsaturation coefficients $\left(K_{u}, K_{s}\right)$ and $R^{*}$ values for these organisms are apparently not influenced by cell size (see below).

At present, it is not possible to construct a similar resource tradeoff curve for potentially competing marine planktonic diatoms because few, if any, appropriate data are available on the uptake or growth relation- 


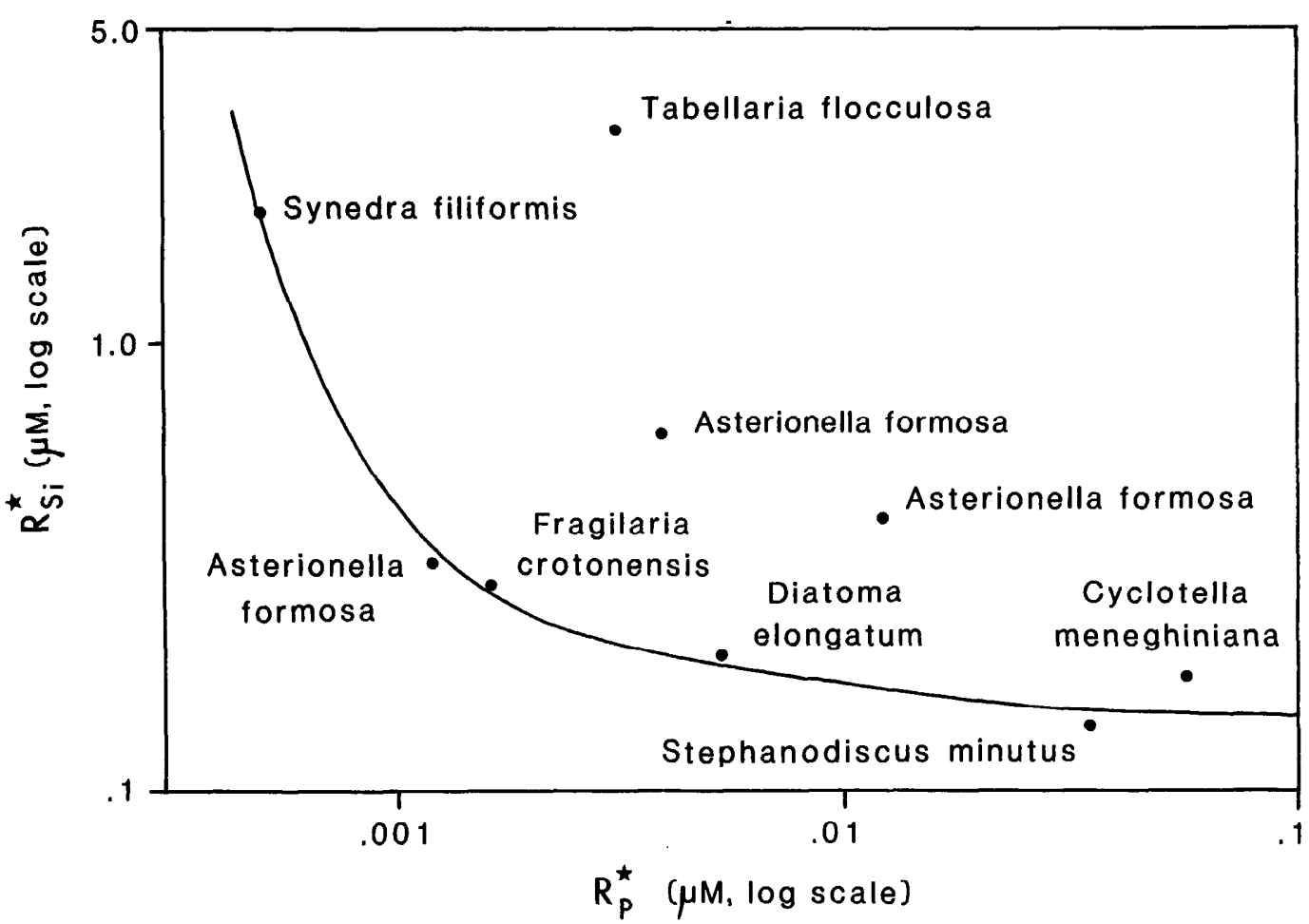

Fig. 5. Curve illustrating interspecific tradeoffs in the competitive abilities of freshwater planktonic diatoms at $20^{\circ} \mathrm{C}$. Synedra filiformis is the superior competitor for phosphate but the most inferior competitor for silicate. In contrast, $S$. minutus is the best competitor for silicate and the worst competitor for phosphate. The data presented are from Tilman et al. (1982, table 1). (Modified from Tilman et al. 1982).

ships of marine diatoms limited by anything other than inorganic nitrogen. Thalassiosira oceanica (formerly $T$. pseudonana, clone 13-1: Hasle 1983) is one of the few marine diatoms for which there are data on the uptake (as defined for each study) of phosphorus (Fuhs et al. 1972), silicon (Nelson et al. 1976), and inorganic nitrogen (nitrate: Carpenter and Guillard 1971; nitrate and ammonium: Eppley and Renger 1974). However, it takes data for more than one species to construct a resource tradeoff curve.

The apparent role of size in determining half-saturation cocfficients for growth and uptake of unicellular algae has long been a subject of debate (Hecky and Kilham 1974; Parsons and Takahashi 1974; Sommer and Kilham 1985; Smith and Kalff 1985). This is an important question because if halfsaturation coefficients are largely a function of size, they may not be the result of selection for competitive dominance over evolutionary time.
A relationship between cell size and halfsaturation coefficients for uptake $\left(K_{s}\right)$ was first hypothesized by Eppley et al. (1969). Using data for nitrate and ammonium, they suggested that large-celled species had higher $K_{s}$ values than small-celled species. They also observed that large-celled neritic species had higher $K_{s}$ values than smaller oceanic species. However, Malone (1980) reanalyzed their data and showed that even though the $K_{s}$ values for nitrate increase with cell size, there are often wide ranges of $K_{s}$ values for each cell size. This makes strong conclusions regarding the relationship between cell size and $K_{s}$ values difficult.

The relationship between phosphorus uptake, size, and the ratio of surface area to volume was studied under field conditions by Friebele et al. (1978). They found that volume-specific uptake rates were approximately proportional to the square of the surface-to-volume ratio. They also concluded, on the basis of a literature review, that 
the relationship between cell size and halfsaturation coefficients for marine phytoplankton is quite unclear.

There is a general relationship between cell size and half-saturation coefficients for nitrogen uptake, but this relationship is not as strong as it originally appeared. One must remember, however, that $R^{*}$ values, and not half-saturation coefficients for uptake per se, play a role in determining the outcome of competition. Consequently, potentially competing marine phytoplankton may eventually be found to have interspecific tradeoffs in their abilities to compete for limiting resources. To date, tradeoffs of this sort have not been reported for marine algae, but probably they have not been looked for.

Many biological oceanographers and a few limnologists believe that aquatic systems never approach equilibrium because of mixing. Thus, they conclude that resource competition among phytoplankton is unlikely to be an important process in most natural environments (Harris 1983). At present these arguments are largely theoretical and few relevant data are available. We are continually impressed by the ability of the resource ratio hypothesis to explain species shifts in diatom populations during the course of seasonal succession (Tilman et al. 1982; Kilham and Kilham 1984; Sommer $1985 b$; Kilham et al. 1986), as well as species shifts observed for diatom microfossils in sediment cores (representing more than 20,000 yr for some African lakes: Kilham et al. 1986). In our opinion, the resource ratio hypothesis must be judged by how well it explains natural phenomena, not by preconceived notions concerning the stability of the environment.

\section{$\mathrm{r}$ - and $\mathrm{K}$-selection in marine and freshwater environments}

The concept of $r$ - and $K$-selection has been profitably applied to marine and freshwater phytoplankton (Kilham and Kilham 1980; Sommer 1981; Reynolds 1984). This concept is particularly useful if one wishes to relate the physico-chemical characteristics of the environment to the biological properties of planktonic algae. Because the concept of $r$ - and $K$-selection does not depend on specific limiting resources or types of predators, it is equally applicable to marine and freshwater organisms. Even though $r$ - and $K$-selection are often referred to as separate entities, they represent a continuum of life-history strategies. $r$-selected organisms are considered to have evolved in unstable or newly formed habitats. They have high population growth rates, but they cannot maintain high population densities for long; either the environment changes or they are outcompeted by other organisms. $K$-selected species are thought to have evolved at or near the carrying capacity of the environment. As a result, they use resources efficiently and their competitive ability is high. Small $r$-selected algac allocate resources primarily to reproduction, while $K$-selected algae allocate resources to a variety of nonreproductive activities that maximize the genetic survival of individuals. These include activities that enhance an individual's ability to obtain and store resources and adaptations that reduce mortality (e.g. large size, manufacture of toxins, body armor, symbionts, etc.).

The concept of $r$ - and $K$-selection was formally stated by MacArthur and Wilson (1967) in terms of the parameters of the logistic equation, where $r$ is the intrinsic rate of growth and $K$ is the asymptote of the growth curve (or carrying capacity). However, the basic biological properties associated with the $r$ - through $K$-selection continuum are not necessarily related to the parameters of the logistic equation. Larger, more $K$-selected organisms, for example, may have lower death rates, but this is not explicitly recognized by the terminology used (see Hairston et al. 1970; Wilbur et al. 1974).

The basic ideas underlying these concepts have been expressed by numerous biologists for more than a century. Winogradsky (1924) argued that soil microbes had contrasting biological properties. He used the term "zymogenous" to describe organisms that respond rapidly to organic substrates that become available in the soil. Other microbes that did not respond to newly available substrates, but subsisted on more refractory organic materials, he termed "autochthonous."

In order to understand how concepts of $r$ - and $K$-selection can be applied to marine 
and freshwater phytoplankton, it is instructive to contrast and compare the seasonal succession of phytoplankton in the subtropical northern Sargasso Sea off Bermuda (Hulburt et al. 1960) with the successional sequence observed in Lake Victoria, Uganda (Talling 1966). These data sets were selected because there are few data, even today, for the annual cycle of phytoplankton in the open ocean other than the observations for the Sargasso Sea. Owing to our interest in African limnology, we have chosen to compare Lake Victoria and the Sargasso Sea. A similar comparison could be made for Lake Lanao, Philippines (see Lewis 1978). The temperature of the Sargasso Sea ranges from $19^{\circ}$ to $28^{\circ} \mathrm{C}$ (Menzel and Ryther 1960); Lake Victoria shows less variation, $23^{\circ}-26^{\circ} \mathrm{C}$ (Talling 1966). The Sargasso Sea is very clear ( $1 \%$ of surface light at a depth of $95 \mathrm{~m}$ : Clarke 1954); Lake Victoria is more turbid (1\% of surface light at ca. $14 \mathrm{~m}$ : Talling 1965). The maximum depth of mixing is about $400 \mathrm{~m}$ (the location of the permanent thermocline) in the Sargasso Sea and about $65 \mathrm{~m}$ (the depth of the lake where it was sampled) in Lake Victoria. Published nutrient analyses for the Sargasso Sea are probably now suspect because improved analytical techniques have become available, but they indicate that nutrient concentrations are generally low $\left(\mathrm{PO}_{4}{ }^{3-}=\right.$ $0.02-0.16 \mu \mathrm{M} ; \mathrm{NO}_{3}{ }^{-}+\mathrm{NO}_{2}{ }^{-}=0.0-1.8$ $\mu \mathrm{M} ; \mathrm{NH}_{4}{ }^{+}=0.0-2.3 \mu \mathrm{M} ; \mathrm{SiO}_{2}=0.3-1.8$ $\mu \mathrm{M}$ : Menzel and Ryther 1960; Menzel and Spaeth 1962). Except for silicon $\left(\mathrm{SiO}_{2}=50\right.$ $75 \mu \mathrm{M}$ ), nutrient concentrations in the epilimnion of Lake Victoria are also near or below the limit of detection $\left(\mathrm{NO}_{3}{ }^{-}=<0.7\right.$ $\mu \mathrm{M} ; \mathrm{PO}_{4}{ }^{3-}=<0.2 \mu \mathrm{M}$ : Talling 1966).

Lake Victoria is eutrophic, and Talling (1965) measured rates of gross primary production between 5.4 and $11.4 \mathrm{~g} \mathrm{O}_{2} \mathrm{~m}^{-2} \mathrm{~d}^{-1}$ (2.0-4.2 $\mathrm{g} \mathrm{C} \mathrm{m}^{-2} \mathrm{~d}^{-1}$ ) with the light and dark bottle technique. Chlorophyll $a$ values are proportionately high in the euphotic zone (Chl $a=1.2-5.5 \mathrm{mg} \mathrm{m}^{-3}$ : Talling 1966). In contrast, rates of primary production are lower in the more oligotrophic Sargasso Sea, but how much lower remains a topic of debate today just as it was in the late 1950s (Menzel and Ryther 1960; Laws et al. 1984; Sheldon 1984). Most recent data on the primary productivity of the open ocean have been collected with the ${ }^{14} \mathrm{C}$ technique, so they may not be directly comparable to measurements based on the $\mathrm{O}_{2}$ method (see Williams et al. 1983). Menzel and Ryther (1960), using the ${ }^{14} \mathrm{C}$ technique, observed rates of "gross" primary production between 0.13 and 2.00 (average 0.44 ) $\mathrm{g} \mathrm{C} \mathrm{m}^{-2}$ $\mathrm{d}^{-1}$. Chlorophyll $a$ values ranged from about 0.05 to $1.0 \mathrm{mg} \mathrm{m}^{-3}$ in the upper $100 \mathrm{~m}$ over the course of a year.

Both data sets for phytoplankton are somewhat inadequate in that only conspicuous algae were counted (Hulburt et al. 1960; Talling 1966). Using epifluorescence microscopy, Murphy and Haugen (1985) have reported high concentrations of chroococcoid (e.g. Synechococcus) blue-green algae (=cyanobacteria) for the northern Sargasso Sea $\left(10^{6}-10^{8}\right.$ cells liter $\left.{ }^{-1}\right)$. Eucaryotes were less numerous (ca. $10^{6}$ cells liter $^{-1}$ ). In Lake Victoria, the offshore phytoplankton was often dominated by colonial chroococcoid blue-green algae (e.g. Aphanocapsa), which were impractical to count (Talling 1966). The scasonal succession of chroococcoid blue-green algae has not been studicd in either the Sargasso Sea or Lake Victoria.

The $D / S$ ratio (resource demand/resource supply) can be used to relate organisms qualitatively along an $r$ - to $K$-selection continuum to the availability of resources in the environment (Pianka 1972; Kilham and Kilham 1980). When resources are scarce, the $D / S \rightarrow 1$ and more $K$-selected organisms arc favored. At $D / S$ ratios considerably $<1$, more $r$-selected organisms predominate.

Three stages of phytoplankton succession are recognized in the Sargasso Sea (Fig. 6; Hulburt et al. 1960). The first begins after the spring bloom, when nutrients decline and the environment becomes increasingly stable $(D / S \rightarrow 1)$. This period lasts from May until October. Changes in the physical environment such as increasing temperature apparently favor dinoflagellates over coccolithophores in late summer, but the diversity and overall abundance remain more or less the same. All of the dinoflagellates and most of the coccolithophores (see below) present at this stage of succession are considered to be strongly $K$-selected.

The equilibrium phytoplankton community present at this time gives values for the equitablity component of species diver- 
Stage of succession

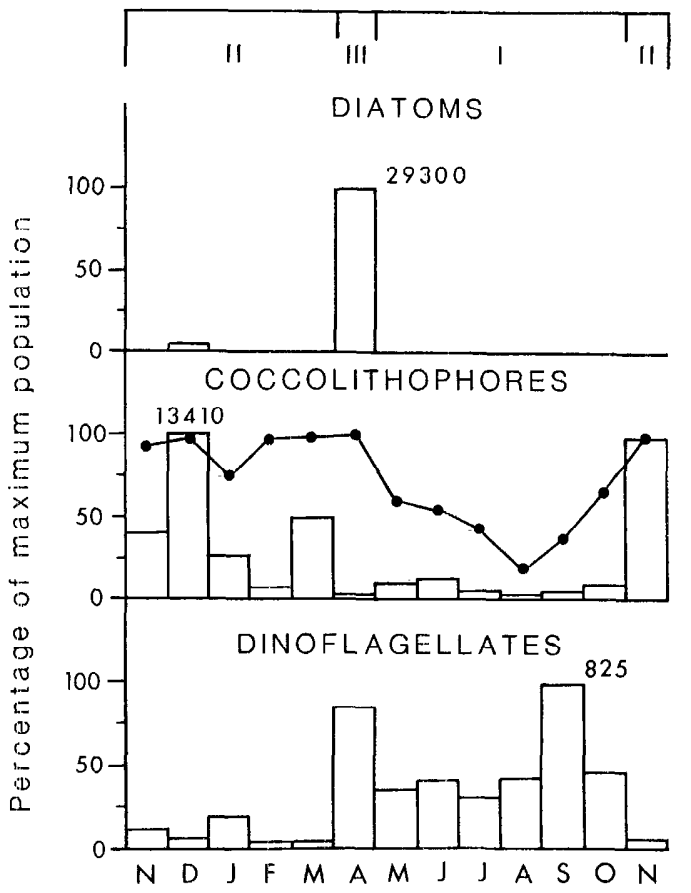

Fig. 6. Seasonal changes among diatoms, coccolithophores, and dinoflagellates in the surface waters $(0-10 \mathrm{~m})$ of the Sargasso Sea off Bermuda (November 1957 through 1958). Data are presented as the percentage of the maximum observed concentration found for cach group. The percentage of Emiliania huxleyi in the total coccolithophore population is shown by the solid linc. Original data for phytoplankton in the Sargasso Sea are from Hulbert et al. (1960). (Redrawn and modified from Smayda 1980.)

sity between 0.65 and 1.0. Theoretically, communities in equilibrium should have cquitability values that approach 1.0 (see Kilham and Kilham 1980).

The second stage of succession begins as the summer thermocline breaks down in November. As a result, nutrient levels increase and the $D / S$ ratio oscillates below 1 . At the same time, the light available per cell decreases because of deeper mixing. Only one species of coccolithophore is markedly favored during this stage. Between November and March, Emiliania (Coccolithus) huxleyi dominates the phytoplankton (Fig. 6). The second stage of succession in the Sargasso Sea is an example of intracommunity succession in that it represents a shift in abundances (primarily of one organism) rather than the appearance of different species.

Emiliania huxleyi is a remarkable coccolithophore because it responds to enrichment. Only one other member of this group, Gephyrocapsa oceanica, behaves in a similar manner. All of the remaining coccolithophores (about 20 species in the western North Atlantic) are $K$-selected and do not respond to enrichment under any circumstances (Hurlburt 1983). Emiliania huxleyi and $G$. oceanica are clearly the most $r$-selected coccolithophores, but they are not eliminated from the equilibrium community under stable conditions when $D / S \rightarrow$ 1. The ecology of the oceanic coccolithophores is largely unknown, but several laboratory studies concerning oceanic phytoplankton (including several species of coccolithophores) have recently been carried out. Brand and Guillard (1981) studied the effects of continuous light and light intensity on growth rate for $E$. huxleyi, $G$. oceanica, and Coccolithina leptospora from the Sargasso Sea. Subsequently, Brand et al. (1983) investigated reproductive rates when zinc, manganese, and iron are limiting for five species of coccolithophores (including the three listed above) isolated from the Gulf of Mexico. These and other data indicate that E. huxleyi is both the smallest (about $7.5 \mu \mathrm{m}$ : Hulburt 1983) and the fastest growing ( $>2$ divisions $d^{-1}$ : Brand and Guillard 1981) of the oceanic coccolithophores.

The third stage of succession begins abruptly in April when the water column again becomes thermally stratified (Hulburt et al. 1960) and the $D / S$ ratio falls considerably below 1 (Kilham and Kilham 1980). When nutrients and light become available in the mixed layer, diatoms immediately flower. Most of the diatoms that grow exponentially during this period are fugitive $r$-selected species not observed among the phytoplankton before they bloom. However, there are several specics that appcar in low numbers at other times. Two diatom species that dominate during the spring bloom (Rhizosolenia stolterfothii and Bacteriastrum delicatulum) are also observed during the second stage of succession.

Succession in Lake Victoria is less easy to characterize because mixing events are 
more loosely linked to the seasonal cycle. All of the data discussed for Lake Victoria come from Talling (1966), but our interpretations may at times differ from his.

The first stage of succession in Lake Victoria is similar to the first stage of succession in the Sargasso Sea (Figs. 6, 7) and occurs when the lake is thermally stratified and nutrients are relatively homogeneous above a depth of about $20 \mathrm{~m}$. This stage is dominated by nitrogen-fixing blue-green algae (Anabaena flos-aquae and Anabaenopsis tanganyikae). There are also smaller fluctuating populations of Lyngbya circumcreta (a filamentous blue-green alga) and Nitzschia acicularis (a pennate diatom). Both small and large forms of Stephanodiscus astraea (a centric diatom) are abundant and remain abundant throughout the year. The first stage of succession is best developed between September and December.

Isothermal mixing of the water column in January begins the second stage of succession. Perhaps owing to light limitation (as a consequence of deeper mixing), there is a precipitous decline in the populations of nitrogen-fixing blue-green algae (Talling 1966). This mixing markedly enhances the growth of several diatoms ( $N$. acicularis and Surirella nyassae).

The next mixing event, which occurred in March, was apparently stronger, and the meroplanktonic diatom Melosira nyassensis v. victoriae was stirred up from the sediments to take its place as a dominant species. This third stage of succession is characterized by the dominance of this diatom.

In Lake Victoria, the $D / S$ ratio remains close to 1 for most of the year, and nutrient levels (except for silicon) are at or near the level of detection at all times. However, the $D / S$ ratio probably falls slightly at the beginning of each mixing event, when nutrients regenerated in the hypolimnion are mixed throughout the water column and light is less available because of deeper mixing. The residence time of Lake Victoria is about 115 yr (using data in Serruya and Pollingher 1983), and regenerated nutrients from zooplankton may well supply most of the nutrients available for phytoplankton in the epilimnion when the lake is stratified.

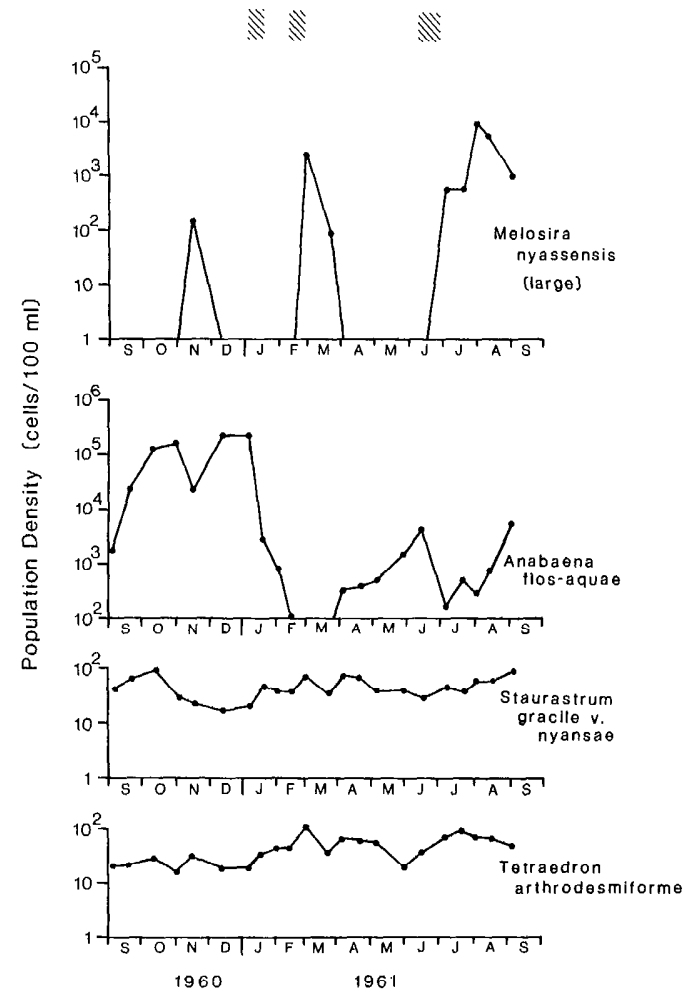

Fig. 7. Changes in population density for four species of algae in Lake Victoria, Uganda. Samples were collected at $0 \mathrm{~m}$ from an offshore station in the lake. Melosira nyassensis is a meroplanktonic diatom. Anabaena flos-aquae is a nitrogen-fixing blue-green alga. Staurastrum gracile v. nyansae is a desmid. Tetraedron arthrodesmiforme is a green alga. Periods of transition to more isothermal and vertically mixed conditions are indicated by the crosshatched blocks. (Based on Talling 1966.)

All of the phytoplankton species in Lake Victoria whose populations were followed fall between the middle and the $K$-selected cnd of the $r$-through $K$-selection continuum. None can be classified as clearly $r$-selected. As in the Sargasso Sea, diatoms respond most readily to enrichment and often obtain high biomasses, but in Lake Victoria some diatoms persist because silicon is always available. Large and small forms of Stephanodiscus astraea are present throughout the year in the lake, and their populations fluctuate less than the other diatoms. Sommer (1981) identificd S. astraea as one of the most $K$-selected algae in Lake Constance (Germany).

Many of the $K$-selected algae in Lake Vic- 
toria maintain low and relatively constant population levels throughout the year. These include the dinoflagcllate Ceratium brachyceros and a large number of green algae (including desmids). Some of the species of green algae that fluctuate little are Tetraedon arthrodesmiforme, Botryococcus braunii, Staurastrum leptocladum, and Staurastrum gracile $\mathrm{v}$. nyansae. Populations of these organisms increase slightly during mixing periods, then decline somewhat during stratified periods (Fig. 7). Species in the dinoflagellate genus Ceratium and the desmid genus Staurastrum were recognized by Sommer (1981) as being among the most $K$-selected phytoplankton in Lake Constance.

The role of blue-green algae in Lake Victoria and in the Sargasso Sea is equivocal because little is known about the small chroococcoid species that are often numerically dominant in both environments. $\mathrm{Ni}$ trogen-fixing blue-green algae are abundant during the first stage of succession in Lake Victoria, and they are also observed during the same stage of succession in the Sargasso Sea [e.g. Oscillatoria (Trichodesmium) thiebautii; see Hulburt et al. 1960; Carpenter 1983]. The nitrogen-fixing blue-green algae respond negatively to deeper mixing (lower light) in Lake Victoria, and they probably occupy an intermediate position on the $r$-through $K$-selection continuum. The most $\mathrm{K}$-selected blue-green alga in the lake is $\mathrm{Mi}$ crocystis wesenbergii (which is similar to or the same as $M$. aeruginosa: Ahlgren 1985). Microcystis wesenbergii is apparently a storage specialist that can utilize large nutrient pulses as they become available in the cnvironment (see above). Its population density fluctuated little during the course of Talling's investigations, and its ecological behavior was similar to that of many of the grcen algae. Reynolds (1984) singled out Microcystis as an example of a $K$-selected phytoplankter because it grows slowly in nature and is often dominant during stable or persistent stratification.

The pattern of succession among major groups of algae in Lake Victoria and in the Sargasso Sea is remarkably similar. This is especially true if one considers some of the freshwater green algae (and desmids in par- ticular) to be functionally equivalent to the $K$-selected marine coccolithophores. Enrichment in both environments stimulates the growth of diatoms, while stable, nutrient-poor conditions are characterized by coccolithophores or green algae (including desrnids), dinoflagellates, and blue-green algae. The successional pattern in Lake Constance differs somewhat from Lake Victoria and the Sargasso Sea because small, highly $r$-selected algae are dominant in the spring (Sommer 1981). They include cryptomonadis, diatoms, and small green algae. The successional pattern later in the year involves more $K$-selected algae that are generally similar to those in Lake Victoria.

Predictions resulting from the resource ratio hypothesis can be used to explain the relative abundances of species in both the Sargasso Sea and Lake Victoria. Tilman (1982), using Hulburt's (1985) observations for the southern Sargasso Sea, suggested that there are five to seven codominant species and numerous rarer coexisting species in that environment because there are several potentially limiting nutrients (see above). A similar situation exists in Lake Victoria. In contrast, during the summer in Casco Bay, Maine (Hulburt 1985), and in Lake Albert (=Mobutu Sese Seko), Uganda (Talling 1963; Kilham et al. 1986), where only one nutrient is apparently limiting, one species of diatom becomes the overwhelming dominant. In Casco Bay, nitrogen is believed to be limiting, and $S$. costatum fluorishes. Silicon is probably limiting in Lake Albert, and $S$. astraea is the dominant diatom.

The resource ratio hypothesis can also be used to predict which genera of euplanktonic diatoms among Stephanodiscus, Nitzschia (except $N$. fonticola, which is associated with Microcystis colonies), and Synedra will be dominant in African lakes (Kilham et al. 1986). The genus Melosira is not included because abundances of these meroplanktonic diatoms are controlled primarily by mixing rather than by competitive interactions. For African lakes with hypolimnia it is possible to correlate the $\mathrm{Si}: \mathrm{P}$ ratio of the submixing zone (the region below the mixed layer from which nutrients diffuse) with the abundances of particular diatom genera in the epilimnion. In Lake Victoria, 
Table 3. Ecological and physiological properties and parameters correlated with $r$ - and $K$-selection in phytoplankton. Physiological information for $r$-selected algac is based on Goldman and Glibert (1983). Hypothetical correlates (developed with the aid of S. S. Kilham) are presented for $K$-selected organisms because experimental data are not available. Storage specialists occupy an intermediate position on the $r$-through $K$-selection continuum. They are physiologically similar to $r$-selected organisms, but they grow more slowly and thus deplete their internal nutrient stores less rapidly. A more detailed evaluation of the criteria of $r$ - and $K$-selection is presented in Kilham and Kilham (1980) and Sommer (1981). In this table, $k_{Q}$ is the minimum cell quota and $Q_{m}$ is the maximum cell quota. The cell quota is the nutrient content per cell.

\begin{tabular}{lll}
\hline \hline \multicolumn{1}{c}{ Propertics and parameters } & \multicolumn{1}{c}{$r$-selected } & $K$-selected \\
\hline Maximum growth rate, $\mu_{m}$ & High & Low \\
Combined loss rates & High & Low \\
Enhanced uptake rates, $V^{\prime}{ }_{m}$ & Very high at $k_{Q}$ & Low or none \\
Variabilty of growth rate, $\mu^{\prime} \mu_{m}$ & Wide range & Narrow range \\
Relationship between $Q_{m}$ and $k_{Q}$ & $Q_{m} \gg k_{Q}$ & $Q_{m} \cong k_{Q}$ \\
Size of individual cells & Small & Large* \\
\hline
\end{tabular}

* Cells may be large relative to other cells in a phytoplankton community or they may be large relative to other taxonomically related organisms.

the $\mathrm{Si}: \mathrm{P}$ ratio of the submixing zone (e.g. 50-m depth; December 1960) is about 86. This number is quite variable in Lake Victoria, but it indicates on the basis of data for most of the other African great lakes that Stephanodiscus and Nitzschia species should predominate in the lake, which is what Talling (1966) observed.

\section{Conclusions}

The information presented in this review indicates that the ecology of marine and freshwater phytoplankton is fundamentally similar. The field of phytoplankton ecology would be better served if the artificial barriers that separate its main branches were completely broken down. It is even likely that critical re-examination of the importance of nitrogen as the major limiting nutrient in the sea (see Hecky and Kilham 1988) and investigations to determine the importance of resource competition among marine phytoplankton will further demonstrate the similarities between marine and freshwater phytoplankton.

Even though marine and freshwater phytoplankton are ecologically similar, there are major differences in the ecology of phytoplankton in general along the $r-K$-selection continuum. Most experimental rescarch on the physiological ecology of phytoplankton has been done with $r$-selected species, which are easy to grow. The ecology of $K$-selected species, on the other hand, is less well understood.

$r$ - and $K$-selected phytoplankton species differ in their ecological and physiological properties (Table 3). $r$-selected organisms have high growth rates, and they can rapidly exploit nutrient patches that become available in the environment. Various algae have been shown to have enhanced nutrient uptake when their cell quotas are less than the maximum value (Goldman and Glibert 1982). The greatest enhancement occurs when the nutrient content of the cell is near the minimum cell quota. The growth rate of $r$-selccted organisms can vary greatly depending on the availability of resources.

There are very few data on the physiological properties of $K$-selected phytoplankton, so we have presented our own hypothetical correlates in Table 3 . These organisms are incapable of responding significantly to enrichment because they have maximum cell quotas that are near to or a little larger than their minimum cell quotas. As a result, their growth rates can approach maximum values much of the time, although their maximum growth rates are slow. Owing to their slow growth rates, these organisms must also have comparatively low loss rates (Sommer 1981) or they could not sustain relatively stable populations in nature (see Fig. 7). Many $K$-selected algae escape from grazing by zooplankton because they are large, colonial, or toxic, while many small $r$-selected organisms are heavily grazed (Lehman and Sandgren 1985; Guillard and Kilham 1977). The strongly $K$-selected algae are adapted to utilize even the low ambient nutrient levels in oligotrophic environments. They take up nutrients slowly, but their growth rates are concomitantly low. 
Competition experiments with a chemostat and several pulsed continuous cultures (see section on patchiness) indicate that species along the $r-K$-selection continuum may respond in different ways to nutrient pulses. Sommer's (1985a) experiments show that some apparently $K$-selected species appear to be affinity specialists in chemostats, and velocity specialists in pulsed state experiments (e.g. $S$. acus). But most of the more $K$-selected algae have remarkably stable populations in the pulsed continuous cultures (e.g. Staurastrum cingulum and $P$. duplex). Sommer classified these species as storage specialists because their numbers fluctuated little and they did not grow in the chemostat experiments, but he pointed out that he could not otherwise distinguish them from affinity specialists.

The work of Sakshaug and Olsen (1986) and Reinertsen et al. (1986) indicated that desmids such as $S$. luetkemuelleri are strongly $K$-selected. They are affinity specialists whose physiology conforms to the model presented in Table 3 . In contrast, blue-green algae such as Anabaena flosaquae and $M$. aeruginosa are storage specialists that appear to occupy a more intermediate position on the $r$ - through $K$ selection continuum. These organisms are physiologically similar to $r$-selected organisms (Table 3) except that they grow more slowly and thus do not utilize their internal stores as rapidly. Strongly $r$-selected species often are velocity specialists with high maximum growth rates that utilize their internal stores very quickly.

Stable, nutrient-poor environments are dominated by both affinity and storage specialists. The affinity specialists take up nutrients more or less continuously even from very low ambient concentrations. Storage specialists, on the other hand, take up and store nutrients obtained from nutrient pulses that periodically become available as a result of animal excretion or other sources. Strongly $K$-selected affinity specialists and morc intermediate storage specialists are characterized by low growth rates and concomitantly low loss rates.

On the basis of ecological information, marine and freshwater phytoplankton can be ranked along an $r$ - through $K$-selection continuum. Eventually, organisms along such a continuum will undoubtedly be shown to have marked differences in physiology. The $r$ - through $K$-selection continuum can serve as a unifying concept for phytoplankton ecology.

\section{References}

Ahlgren, G. 1985. Growth of Microcystis wesenbergii in batch and chemostat cultures. Int. Ver. Theor. Angew. Limnol. Verh. 22: 2813-2820.

BOLD, H. C., AND M. J. WYNNE. 1985. Introduction to the algae, 2 nd ed. Prentice-Hall.

Brand, L. E., AND R. R. L. Guillard. 1981. The effects of continuous light and light intensity on the reproduction rates of twenty-two species of marine phytoplankton. J. Exp. Mar. Biol. Ecol. 50: 119-132.

- W. G. Sunda, AND R. R. L. GuILlard. 1983. Limitation of marine phytoplankton reproductive rates by zinc, manganese, and iron. Limnol. Occanogr. 28: 1182-1198.

BrokCKeR, W. S. 1974. Chemical oceanography. Harcourt Brace Jovanovich.

Butron, D. K. 1985. Kinetics of nutrient-limited transport and microbial growth. Microbiol. Rev. 49: 270-297.

CARPENTER, E. J. 1983. Nitrogen fixation by marine Oscillatoria (Trichodesmium) in the world's oceans, p. 65-103. In E. J. Carpenter and D. G. Capone [eds.], Nitrogen in the marine environment. Academic.

- AND D. G. CAPONE [EDS.]. 1983. Nitrogen in the marine environment. Academic.

—_ AND R. R. L. GUILlaRd. 1971. Intraspecific differences in nitrate half-saturation constants for three species of marine phytoplankton. Ecology 52: 183-185.

Clarke, G. L. 1954. Elements of ecology. Wiley.

CURRIE, D. J. 1984. Microscale nutrient patches: Do they matter to phytoplankton? Limnol. Oceanogr. 29: 211-214.

Droop, M. R. 1974. The nutrient status of algal cells in continuous culture. J. Mar. Biol. Assoc. U.K. 54: $825-855$.

- 1983. 25 years of algal growth kinetics: A personal view. Bot. Mar. 26: 99-112.

Dugdale, R.C. 1967. Nutrient limitation in the seas: Dynamics, identification, and significance. Limnol. Oceanogr. 12: 685-695.

Elrifi, I. R., AND D. H. TuRPIN. 1985. Steady-state luxury consumption and the concept of optimum nutrient ratios: A study with phosphate and nitrate limited Selenastrum minutum (Chlorophyta). J. Phycol. 21: 592-602.

EPPley, R. W., AND E. M. RenGer. 1974. Nitrogren assimilation of an oceanic diatom in nitrogen-limited continuous culturc. J. Phycol. 10: 15-23.

- J. N. Rogers, AND J. J. MCCARThy. 1969. Half-saturation constants for uptake of nitrate and ammonium by marine phytoplankton. Limnol. Oceanogr. 14: 912-920. 
Friebele, E. S., D. L. Correll, and M. A. Faust. 1978. Relationship between phytoplankton cell size and the rate of orthophosphate uptake: In situ observations of an estuarine population. Mar. Biol. 45: $39-52$.

Fuhs, G. W., S. D. Demmerle, E. Canelli, and M. CHEN. 1972. Characterization of phosphoruslimited plankton algae (with reflections on the limiting-nutrient concept). Am. Soc. Limnol. Oceanogr. Spec. Symp. 1: 113-133.

Goldman, J. C., and P. M. Glibert. 1982. Comparative rapid ammonium uplake by four marine phytoplankton species. Limnol. Oceanogr. 27: 814 827.

, AND - 1983. Kinetics of inorganic nitrogen uptake by phytoplankton, p. 233-274. In E. J. Carpenter and D. G. Capone [cds.], Nitrogen in the marine environment. Academic.

- AND J. J. MCCARThy, 1978. Steady state growth and ammonium uptake of a fast-growing marine diatom. Limnol. Oceanogr. 23: 695-703.

Guillard, R. R. L., AND P. Kilham. 1977. The ecology of marine planktonic diatoms, p. 372-469. In D. Werner [ed.], The biology of diatoms. Blackwell.

Hairston, N. G., D. W. Tinkle, and H. M. Wilbur. 1970. Natural selection and the parameters of population growth. J. Wildl. Manage. 34: 681690

HArris, G. P. 1983. Mixed layer physics and phytoplankton populations: Studies in equilibrium and non-cquilibrium ecology. Prog. Phycol. Res. 2: 152.

HARrison, P. J., AND D. H. Turpin. 1982. The manipulation of physical, chemical, and biological factors to sclect species from natural phytoplankton populations, p. 275-289. In G. D. Grice and M. R. Reeve [eds.], Marine microcosms-biological and chemical research in experimental ecosystems. Springer.

HARRISON, W. G. 1983. Nitrogen in the marine environment: Use of isotopes, p. 763-807. In E. J. Carpenter and D. G. Capone [eds.], Nitrogen in the marine environment. Academic.

Hasle, G. R. 1983. The marine, planktonic diatoms Thalassiosira oceanica $\mathrm{sp}$. nov. and T. partheneia. J. Phycol. 19: 220-229.

Healey, F. P. 1980. Slope of the Monod equation as an indicator of advantage in nutrient competition. Microb. Ecol. 5: 281-286.

-1985. Interacting effects of light and nutrient limitation on the growth rate of Synechococcus linearis (Cyanophyceac). J. Phycol. 21: 134-146.

HeCKy, R. E., AND P. Kilham. 1974. Environmental control of phytoplankton cell size. Limnol. Oceanogr. 19: 361-366.

— AND —. 1988. Nutrient limitation of phytoplankton in freshwater and marine environments: A review of recent evidence on the effects of enrichment. Limnol. Oceanogr. 33: 796-822.

Holm, N. P., AND D. E. ARMSTRONG. 1981. Role of nutrient limitation and competition in controlling the populations of Asterionella formosa and $\mathrm{Mi}$ - crocystis aeruginosa in semicontinuous culture. Limnol. Oceanogr. 26: 622-634.

HulburT, E. M. 1983. Quasi K-selected species, equivalence, and the oceanic coccolithophorid plankton. Bull. Mar. Sci. 32: 197-212.

. 1985. Format for phytoplankton productivity in Casco Bay, Maine, and in the southern Sargasso Sea. Bull. Mar. Sci. 37: 808-826.

- J. H. RYTHER, AND R. R. L. GuILlaRd. 1960. The phtyoplankton of the Sargasso Sca off Bermuda. J. Cons. Cons. Int. Explor. Mer 25: 115127.

JACkSON, G. A. 1980. Phytoplankton growth and zooplankton grazing in oligotrophic oceans. Nature 284: 439-441.

Kilham, P., and S. S. Kilham. 1980. The evolutionary ecology of phytoplankton, p. 571-597. In I. Morris [ed.], The physiological ecology of phytoplankton. Univ. California.

- - AND R. E. HECKY. 1986. Hypothesized resource relationships among planktonic diatoms. Limnol. Oceanogr. 31: 1169-1181.

$\longrightarrow$, AND D. G. Titman. 1976. Some biological effects of atmospheric inputs to lakes: Nutrient ratios and competitive interactions between phytoplankton. J. Great Lakes Res. 2(suppl. 1): 187191.

KILHAM, S. S. 1978. Nutrient kinetics of freshwater planktonic algae using batch and semicontinuous methods. Mitt. Int. Ver. Theor. Angew. Limnol. 21, p. $147-157$.

- 1986. Dynamics of Lake Michigan natural phytoplankton communities in continuous culture along a Si : P loading gradient. Can. J. Fish. Aquat. Sci. 43: 351-360.

- AND P. KILHaM. 1984. The importance of resource supply rates in determining phytoplankton community structure, p. 7-27. In Trophic interactions within aquatic ecosystems. Am. Assoc. Adv. Sci. Symp. 85.

LAws, E. A., AND OTHERS. 1984. High phytoplankton growth and production rates in oligotrophic Hawaiian coastal waters. Limnol. Oceanogr. 29: 1161-1169.

Lehman, J. T., AND C. D. Sandgren. 1985. Speciesspecific rates of growth and grazing loss among freshwater algae. Limnol. Oceanogr. 30: 34-46.

- ANd D. Scavia. 1982a. Microscale patchiness of nutrients in plankton communities. Science 216: 729-730.

— AND ——. 1982b. Microscale nutrient patches produced by zooplankton. Proc. Natl. Acad. Sci. 79: 5001-5005.

—_ AND —. 1984. Measuring the ecological significance of microscale nutrient patches. Limnol. Oceanogr. 29: 214-216.

LewIS, W. M., JR. 1978. Dynamics and succession of the phytoplankton in a tropical lake: Lake Lanao, Philippines. J. Ecol. 66: 849-880.

MacArthur, R. H., AND E. O. Wilson. 1967. The theory of island biogeography. Princeton.

MCCarthy, J. J., AND J. C. Goldman. 1979. Nitrogenous nutrition of marine phytoplankton in nutrient-depleted waters. Science 203: 670-672. 
Maestrini, S. Y., AND D. J. Bonin. 1981. Competition among phytoplankton based on inorganic macronutrients. Can. Bull. Fish. Aquat. Sci. 210, p. 264-278.

Malone, T. C. 1980. Algal size, p. 433-463. In I. Morris [ed.], The physiological ecology of phytoplankton. Univ. California.

Menzel, D. W., And J. H. Ryther. 1960. The annual cycle of primary production in the Sargasso Sea off Bermuda. Deep-Sea Res. 6: 351-367.

- AND J. P. SPAETh. 1962. Occurrence of ammonia in Sargasso Sea waters and in rain at Bermuda. Limnol. Oceanogr. 7: 159-162.

Mickelson, M. J., H. Maske, and R. C. Dugdale. 1979. Nutrient-determincd dominance in multispecies chemostat cultures of diatoms. Limnol. Oceanogr. 24: 298-315.

MonOD, J. 1942. Recherches sur la croissance des cultures bacteriennes, 2 nd ed. Hermann.

MORRIS, I. [ED.]. 1980. The physiological ecology of phytoplankton. Univ. Calif.

MurPhy, L. S., AND E. M. Haugen. 1985. The distribution and abundance of phototrophic ultraplankton in the North Atlantic. Limnol. Oceanogr. 30: $47-58$.

Nelson, D. M., J. J. Goering, S. S. Kilham, AND R. R. L. Guillard. 1976. Kinetics of silicic acid uptake and rates of silica dissolution in the marine diatom Thalassiosira pseudonana. J. Phycol. 12: 246-252.

PARSONS, T. R., AND M. TAKAHASHI. 1974. A rebuttal to the comment by Hecky and Kilham. Limnol. Oceanogr. 19: 366-368.

PiankA, E. R. 1972. $r$ and $K$ sclection or $b$ and $a$ selection. Am. Nat. 106: 581-588.

Plate, T. [ED.]. 1981. Physiological bases of phytoplankton ecology. Can. Bull. Fish. Aquat. Sci. 210.

Reinertsen, H., A. Jensen, A. Langeland, ANd Y. OLSEN. 1986. Algal competition for phosphorus: The influence of zooplankton and fish. Can. J. Fish. Aquat. Sci. 43: 1135-1141.

REYNOLDS, C. S. 1984. The ecology of freshwater phytoplankton. Cambridge.

RHEE, G-Y. 1980. Continuous culture in phytoplankton ecology. Adv. Aquat. Microbiol. 2: 151-203. Academic.

— AND I. J. Gotham. 1980. Optimum N:P ratios and coexistence of planktonic algae. J. Phycol. 16: 486-489.

Round, F. E. 1981. The ecology of algae. Cambridge.

SAKShaug, E., AND Y. Olsen. 1986. Nutrient status of phytoplankton blooms in Norwegian waters and algal strategies for nutrient competition. Can. J. Fish. Aquat. Sci. 43: 389-396.

Scavia, D., G. L. Fahnenstiel, J. A. Davis, And R. G. KREIS, JR. 1984. Small-scale nutrient patchiness: Some consequences and a new encounter mechanism. Limnol. Oceanogr. 29: 785-793.

Serruya, C., and U. Pollingher. 1983. Lakes of the warm belt. Cambridge.

SHeldon, R. W, 1984. Phytoplankton growth rates in the tropical ocean. Limnol. Oceanogr. 29: 13421346.
Smayda, T. J. 1980. Phytoplankton species succes sion, p. 493-570. In I. Morris [ed.], The physiological ecology of phytoplankton. Univ. Calif.

Smith, R. E. H., AND J. KalfF. 1983. Competition for phosphorus among co-occurring freshwater phytoplankton. Limnol. Oceanogr. 28: 448-464.

among phytoplankton: A reply. Limnol. Oceanogr. 30: 440-444.

SOMMER, U. 1981. The role of $r$ - and $K$-selection in the succession of phytoplankton in Lake Constance. Oecol. Gen. 2: 327-342.

- 1983. Nutrient competition between phytoplankton species in multispecies chemostat ex periments. Arch. Hydrobiol. 96: 399-416.

- $1985 a$. Comparison between steady state and non-steady state competition: Experiments with natural populations. Limnol. Oceanogr. 30: 335346.

1985b. Seasonal succession of phytoplankton in Lake Constance. BioScience 35: 351-357.

1986. Phytoplankton competition along a gradient of dilution rates. Oecologia 68: 503-506. - AND S. S. Kilham. 1985. Phytoplankton natural community competition experiments: A reinterpretation. Limnol. Oceanogr. 30: 436-440.

TAlising, J. F. 1963. Origin of stratification in an African rift lake. Limnol. Oceanogr. 8: 68-78.

. 1965. The photosynthetic activity of phytoplankton in East African lakes. Int. Rev. Gesamten Hydrobiol. 50: 1-32.

_ 1966. The annual cycle of stratification and phytoplankton growth in Lake Victoria (East Africa). Int. Rev. Gesamten Hydrobiol. 51: 545-621.

Terry, K. L., E. A. Laws, AND D. J. Burns. 1985. Growth rate variation in the $N: P$ requirement ratio of phytoplankton. J. Phycol. 21: 323-329.

TILMAN, D. 1977. Resource competition between planktonic algae: An experimental and theoretical approach. Ecology 58: 338-348.

— 1981. Tests of resource competition theory using four species of Lakc Michigan algae. Ecology 62: 802-815.

- 1982. Resource competition and community structure. Princeton.

icate growth and uptake kinetics of the diatoms Asterionella formosa and Cyclotella meneghiniana in batch and continuous culture. J. Phycol. 12: 375-383.

- - - AND P. Kilham. 1982. Phytoplankton community ecology: The role of limiting nutrients. Annu. Rev. Ecol. Syst. 13: 349-372.

- - - AND - 1984. A reply to Sell, Carney, and Fahnenstiel. Ecology 65: 328-332.

TurPIN, D. H. 1986. Growth rate dependent optimum ratios in Selenastrum minutum (Chlorophyta): Implications for competition, coexistence and stability in phytoplankton communities. J. Phycol. 22: $94-102$.

$\longrightarrow$, AND P. J. HARRISON. 1979. Limiting nutrient patchiness and its role in phytoplankton ecology. J. Exp. Mar. Biol. Ecol. 39: 151-166. 
1980. Cell size manipulation in natural marine, planktonic, diatom communities. Can. J. Fish. Aquat. Sci. 37: 1193-1 195.

Wilbur, H. M., D. W. Tinkle, and J. P. Collins. 1974. Evolutionary certainty, trophic level, and resource availability in life history evolution. Am. Nat. 108: 805-817.
Williams, P. J. LeB., K. R. Heinemann, J. Marra, AND D. A. Purdie. 1983. Comparison of ${ }^{14} \mathrm{C}$ and $\mathrm{O}_{2}$ measurements of phytoplankton production in oligotrophic waters. Nature 305: 49-50.

WinOGRADSKY, S. 1924. Sur la microflore autochtone de la terre arable. C. R. Hebd. Seanc. Acad. Sci. Paris 178: 1236-1239. 